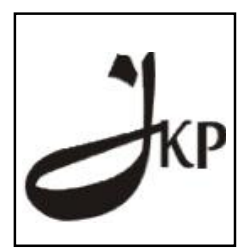

Jurnal Konseling dan Pendidikan

ISSN Cetak: 2337-6740 - ISSN Online: 2337-6880

http://jurnal.konselingindonesia.com

Volume 1 Nomor 1, Februari 2013, HIm 36-42

\title{
Perkembangan Profesional Konselor Untuk Memenuhi Kebutuhan Masyarakat Industri
}

\author{
Fadhila Yusri ${ }^{1}$ \\ ${ }^{1}$ STAIN Bukittinggi
}

\begin{abstract}
Abstrak
Perubahan sosial yang amat cepat dan makin kompleksnya keadaan masyarakat dewasa ini telah terjadi di seluruh belahan dunia. Perubahan itu melahirkan diferensiasi dan situasi global yang berbeda. Masyarakat industri yang tiap hari disibukkan dengan rutinitas pekerjaan dan kariernya. Bekerja di bawah tekanan dan kecemasan akan kesuksesan dalam kariernya. Bahkan banyak diantara mereka yang melupakan bahwasanya di rumah mereka mempunyai anak-anak dan keluarga yang membutuhkan perhatian lebih dan kasih sayang. Kecenderungan kriminalitas meningkat dan kenakalan remaja serta perbuatan-perbuatan yang melampaui norma-norma sosial semakin subur. Kehadiran konselor sepertinya menjawab tantangan zaman dan seiring dengan pesatnya kemajuan pasar global. Kantor berita online, careerbuilder.co.uk menulis dan menempatkan konselor dalam 10 besar profesi yang sangat dibutuhkan di dalam masyarakat saat ini. Alasannya dikemukakan bahwa tekanan hidup yang semakin meningkat membuat banyak orang menderita stres dan mengalami kecemasan berlebihan. Karena itu, tenaga konselor merupakan profesi yang dibutuhkan untuk membantu masyarakat dalam menghadapi berbagai permasalahan kehidupan di zaman globalisasi seperti saat sekarang ini.

Seorang calon konselor yang hanya cukup puas dengan kemampuan dan keahlian serta kompetensi yang sudah dikuasai secara benar dibangku perkuliahan saja tanpa membekali dengan kemampuan (skill) lain. Hal ini, jelas akan menjadi pertanyaan besar, "apakah bisa menembus ketatnya persaingan dunia profesi di pasar global?”. Sementara dunia globalisasi menuntut pekerja profesional yang handal. Oleh karena itu, untuk dapat bersaing di pasar global konselor memang diharapkan untuk selalu mengembangkan kemampuan profesionalnya dibidang konseling. Arah pengembangan profesional konselor hendaknya disesuaikan dengan kebutuhan pasar global, hingga tenaga konselor dapat membantu masyarakat industri keluar dari berbagai permasalahan yang dihadapinya. Pada akhirnya profesi konselor makin dipercayai di tengah masyarakat dengan keprofesionalan tenaga pelaksananya.
\end{abstract}

Keyword:Profesional, mayarakat, industry

Copyright (C) 2013 IICE - Multikarya Kons - All Rights Reserved

Indonesian Institute for Counseling and Education (IICE) Multikarya Kons

\section{PENDAHULUAN}

Perubahan sosial yang amat cepat dan makin kompleksnya keadaan masyarakat dewasa ini telah terjadi di seluruh belahan dunia. Perubahan itu melahirkan diferensiasi dan situasi global yang berbeda. Marzurek (2000)

\footnotetext{
* Telp dan/atau Alamat Email Koresponden : 
Jurnal Konseling dan Pendidikan

menjelaskan bahwa perubahan memungkinkan terjadinya ketidakpastian dan kejutan baru, serta peluang berpartisipasi bagi individu untuk mempertahankan dan eksistensi kehidupannya dan menghasilkan sumber daya manusia yang berkualitas dan produktif.

Masyarakat industri yang tiap hari disibukkan dengan rutinitas pekerjaan dan kariernya. Bekerja di bawah tekanan dan kecemasanakan kesuksesan dalam kariernya. Seringkali banyak pula diantara mereka yang melupakan bahwasanya di rumah mereka mempunyai anak-anak dan keluarga yang membutuhkan perhatian lebih dan kasih sayang. Kecenderungan kriminalitas meningkat dan kenakalan remaja serta perbuatan-perbuatan yang melampaui norma-norma sosial semakin subur.

Di sisi lain, masyarakat perkotaan tak bisa lepas dari fenomena sosial kemiskinan, dan masyarakat yang terpinggirkan. Sikap individualitas muncul, acuh tak acuh terhadap sesama kerabatnya, yang penting hanya uang dan barang. Mata, pikiran serta agama telah fokus pada bagaimana pencapaian materi yang sebanyak-banyaknya. Seks dihargai halal, sebagai pengistirahat dari rasa lelah oleh rutinitas sehari-hari. Sehingga pada akhirnya membuat lahirnya anak-anak tanpa status yang jelas. Pacaran yang melebihi batas-batas nilai etika dan moral, menjadikan hubungan pacaran layaknya hubungan pernikahan.

Begitulah dunia globalisasi saat ini, tanpa batas geografi lagi globalisasi telah menjangkau seluruh cakupan dunia. Negara-negara yang kultural lambat laun menjadi multi kultural. Manusia sebagai bagian dari masyarakat dan lingkungan sosial semestinya mempunyai dimensi individualitas, sosial, moral dan agama. Namun, mereka tampaknya telah lupa pada tujuan hidupnya sendiri dan fitrah lahiriahnya.

Remaja maupun dewasa saat ini akan banyak yang mengalami frustasi eksistensial. Sebetulnya sudah berlangsung dewasa ini, dengan banyaknya kasus kriminal, seks bebas, serta kematian dikarenakan bunuh diri baik para remaja maupun dewasa. Oleh karena itu, keberadaan konselor, psikolog dan pskiater sesungguhnya sangat dibutuhkan dan mempunyai peranan penting di dalam masyarakat industri seperti sekarang ini.

Kehadiran konselor sepertinya menjawab tantangan zaman dan seiring dengan pesatnya kemajuan pasar global. Semakin terbuka dan semakin jauh dekade per dekade, individu akan membutuhkan bimbingan hidup dan layanan konseling lainnya. Ini membuka peluang, bahwasannya saat ini dan ke depan, kebutuhan akan profesi Konseling tidak hanya dapat diselenggarakan di sekolah-sekolah dan institusi pendidikan, tetapi juga harus pula diselenggarakan di bidang-bidang lain seperti industri dan klinis.

Konselor yang dibutuhkan oleh masyarakat industripun tentu tidak sembarang konselor, karena peliknya permasalahan yang dialami oleh masyarakat. Masyarakat industri membutuhkan konselor yang profesional, yang mereka harapkan mampu membantu mereka mengentaskan permasalahan yang mereka hadapi dalam setiap setting kehidupan. Tentu saja itu merupakan tantangan besar bagi konselor terhadap profesionalismenya dalam menjalankan profesinya.

\section{PEMBAHASAN}

\section{Konselor Profesional}

Banyak pertanyaan dari mahasiswa tentang, bagaimana menjadi konselor profesional? Apa yang harus disiapkan untuk menjadi konselor yang profesional? Bagaimana persiapannya? Kompetensi apa saja yang harus dimiliki oleh seorang konselor? Juga beberapa pertanyaan lain dari mahasiswa yang masih merasa bingung akan profesi konselor.

Konselor merupakan suatu profesi yang menjanjikan di masa depan. Menurut Dirjen Dikti Depdiknas (2004:5) profesi merupakan pekerjaan atau karir yang bersifat pelayanan bantuan keahlian dengan tingkat ketepatan yang tinggi untuk kebahagiaan pengguna berdasarkan norma-norma yang berlaku. Kekuatan dan eksistensi profesi muncul sebagai akibat interaksi timbal balik antara kinerja tenaga profesional dengan kepercayaan publik (public trust).

Masih banyak orang yang memandang bahwa pemberian pelayanan konseling dapat dilakukan oleh siapapun juga, asalkan mampu berkomunikasi dan berwawancara. Anggapan lain mengatakan bahwa pelayanan konseling semata-mata diarahkan kepada pemberian bantuan berkenaan dengan upaya pemecahan masalah dalam arti yang sempit saja. Pelayanan konseling tidak semata-mata diarahkan kepada pemecahan masalah saja, tetapi mencakup berbagai jenis layanan dan kegiatan yang mengacu kepada terwujudnya fungsi-fungsi yang luas. Berbagai jenis bantuan dan kegiatan itu menuntut adanya unjuk kerja profesional tertentu.

"Profesional" merujuk pada dua hal. Pertama, orang yang menyandang suatu profesi. Kedua, penampilan seorang dalam melakukan pekerjaan yang sesuai dengan profesinya. Dalam pengertian yang kedua ini, istilah 
Jurnal Konseling dan Pendidikan

profesional sering dipertentangkan dengan istilah non profesional atau amatiran. Istilah di atas menekankan pada kemampuan seseorang pelaksana profesi untuk menjalankan profesinya sesuai dengan tuntutan tugas profesi tersebut, hingga mereka berhak disebut sebagai orang yang profesional.

Dalam UU No. 14/2005 tentang Undang-undang Guru dan Dosen Ps.1 Butir 4 dinyatakan bahwa profesional adalah pekerjaan atau kegiatan yang dilakukan oleh seseorang dan menjadi sumber penghasilan kehidupan yang memerlukan keahlian, kemahiran, atau kecakapan yang memenuhi standar mutu atau norma tertentu serta memerlukan pendidikan profesi. Begitu juga halnya dengan profesi konselor yang dijalankan oleh para konselor diberbagai setting kehidupan.

Konselor profesional membedakan konselor dari para profesional lainnya yang juga menggunakan label konselor/penasehat. Seperti konselor/penasehat keuangan, konseor/penasehat investasi dan sebagainya. Robert L. Gibson dan Marianne H. Mitchell (2011:46) mengungkapkan para profesional adalah perwakilan aktif penuh waktu bagi profesinya, karena itu mereka menerima tanggung jawab akan sebuah profesionalisme.

Tanggung jawab para konselor profesional meliputi hal-hal berikut :

1. Para konselor profesional harus terlatih sepenuhnya dan berkualifikasi agar sanggup memenuhi kebutuhan populasi klien yang mereka tangani atau yang dipercayakan padanya.

2. Para konselor profesional secara aktif harus mencari dan mendapatkan sertifikasi atau lisensi yang tepat sesuai pelatihan, latar belakang dan lingkup praktiknya.

3. Para konselor profesional perlu berkomitmen secara pribadi dan profesional untuk terus memperbaharui dan meningkatkan keahlian dan pengetahuan mereka sebagai cerminan dan representasi kemajuan terbaru bidang profesi mereka.

4. Para konselor profesional menyadari dan berkontribusi bagi pengembangan profesi dengan melakukan dan berpartisipasi dalam studi riset yang dirancang untuk meningkatkan pengetahuan tentang profesinya.

5. Para konselor profesional adalah anggota yang berpartisipasi aktif di dalam organisasi profesi yang tepat di semua tingkatan.

6. Para konselor profesional sadar betul dan taat kepada rambu-rambu legal dan etis profesi dan praktik konseling.

Pelayanan konseling profesional yang diampu oleh konselor berada adalam konteks tugas "kawasan pelayanan yang bertujuan memandirikan individu dalam menavigasi perjalanan hidupnya melalui pengambilan keputusan tentang pendidikan termasuk yang terkait dengan keperluan untuk memilih, meraih serta mempertahankan karir untuk mewujudkan kehidupan yang produktif dan sejahtera, serta untuk menjadi warga masyarakat yang peduli kemaslahatan umum melalui pendidikan".

Ekspektasi kinerja konselor profesional yang mengampu konseling selalu digerakkan oleh motif altruistik dalam arti selalu menggunakan penyikapan yang empatik, menghormati keragaman, serta mengedepankan kemaslahatan pengguna pelayanannya, dilakukan dengan selalu mencermati kemungkinan dampak jangka panjang dari tindak pelayanannya itu terhadap pengguna pelayanan, sehingga pengampu pelayanan profesional itu juga dinamakan the reflective practitioner.

Pelayanan profesional konselor meliputi pemahaman nilai, sikap, keterampilan, dan pengetahuan dibidang konseling. Untuk memahami orang lain dengan sebaik-baiknya, konselor profesional harus terus-menerus berusaha menguasai dirinya. Ia harus mengerti kekurangan-kekurangan dan prasangka-prasangka pada dirinya sendiri. Dalam melakukan tugasnya membantu klien, konselor profesional harus memperlihatkan sifat-sifat sederhana, rendah hati, sabar, menepati janji, dapat dipercaya, jujur, dan tertib. Konselor profesional juga harus memiliki rasa tanggung jawab terhadap saran ataupun peringatan yang diberikan kepadanya, khususnya dari rekan-rekan seprofesi dalam hubungannya dengan pelaksanaan ketentuan-ketentuan tingkah laku profesional sebagaimana diatur dalam kode etik profesi.

Dengan pewujudan berbagai hal terbaik untuk dirinya sendiri dan untuk profesi yang dijalaninya, diharapkan konseling mampu menjadi profesi yang bermartabat. Menurut Prayitno (2008:17) dinyatakan bahwa kemartabatan suatu profesi yang ditampilkan sangat tergantung pada tenaga profesional yang mempersiapkan diri untuk pemegang profesi yang dimaksudkan itu. Keberhasilan dan kebermartabatan suatu profesi tetap tergantung terhadap keprofesionalan tenaga pelaksananya. 
Kemartabatan yang dimaksudkan itu meliputi kondisi sebagai berikut:

a. Pelayanan profesional yang diselenggarakan benar-benar bermanfaat bagi kemaslahatan kehidupan secara luas. Sebagaimana diketahui, upaya pelayanan profesi merupakan hajat hidup semua orang dalam kadar yang sangat mendasar dan penting, dari generasi ke generasi.

b. Pelayanan profesional diselenggarakan oleh petugas atau pelaksana yang bermandat. Sesuai dengan sifatnya yang profesional itu, maka pelayanan profesi yang dimaksud haruslah dilaksanakan oleh tenaga yang benar-benar dipercaya untuk menghasilkan tindakan dan produk-produk pelayanan dalam mutu yang tinggi.

c. Pelayanan profesional yang dimaksudkan itu diakui secara sehat oleh pemerintah dan masyarakat. Dengan kemanfaatan yang tinggi dan dilaksanakan oleh pelaksana yang bermandat, pemerintah dan masyarakat tidak ragu-ragu mengakui dan memanfaatkan pelayanan yang dimaksudkan itu.

\section{Tantangan Konselor Masa Depan}

Sebagai sebuah profesi, seorang konselor yang profesional dituntut mempunyai keahlian dan kompetensi yang memadai. Apalagi di masa saat ini (era globalisasi), bahkan setiap dari individu pun akan mendapatkan persaingan yang terbuka dari individu yang lain untuk memperoleh pekerjaan profesi konselor, jelas akan bersaing pula dengan profesi lain. Apakah layak diterima sebagai profesi yang berguna dan bermanfaat bagi masyarakat atau tidak. Begitu pula dengan sumber daya konselornya.

Mahasiswa program studi Bimbingan Konseling sebetulnya disiapkan menjadi konselor sekolah. Lapangan kerja dibidang ini masih cukup luas. Terutama untuk memenuhi tenaga kerja profesional bidang Bimbingan Konseling di sekolah-sekolah; mulai dari sekolah dasar hingga jenjang perguruan tinggi.

Tenaga kerja bidang bimbingan konseling yang selama ini ada di sekolah-sekolah masih belum layak untuk disebut profesional. Masih banyak diantara tenaga-tenaga kerja tersebut yang tidak mempunyai keahlian dan kompetensi dibidang bimbingan konseling. Misalnya, konselor bukan lulusan dari program studi Bimbingan Konseling atau program studi Psikologi Pendidikan dan Bimbingan. Akibatnya tidak memahami bagaimana cara memberikan layanan bimbingan dan konseling yang berdasarkan atas prinsip psikopaedagogis.

Selain itu, kebijakan pemerintah yang menetapkan rasio 1:150 yang berarti setiap satu konselor bertanggung jawab atas 150 siswa. Menimbulkan implikasi bahwa jumlah konselor yang tadinya tidak atas rasio tersebut harus ditambah. Selama ini kekurangan tenaga konselor di sekolah oleh kepala sekolah ditutupi dengan mengambil tenaga kerja dari jurusan psikologi. Apabila di sekolah-sekolah negeri saja masih kekurangan tenaga konselor profesional, apalagi di sekolah-sekolah swasta.

Seorang konselor, dibekali dengan ilmu-ilmu mengenai pendidikan dan perkembangan peserta didik. Sehingga bukan hal yang baru lagi, jika seorang konselor dapat pula menjadi seorang konsultan pendidikan baik secara privatmaupun untuk layanan pendidikan di sekolah-sekolah. Dengan banyaknya sekolah-sekolah bermunculan, bahkan booming-nya education business, membuat masyarakat semakin bingung menentukan pilihan pendidikan; dimana putra-putrinya akan disekolahkan. Tantangan di pasar global membuat orang tua, memilih institusi pendidikan yang terbaik yang membuat putra-putrinya mendapatkan pendidikan dengan kualitas tinggi walupun dengan biaya mahal.

Paradigma pendidikan adalah investasi masa depan, masih sangat melekat dipikiran masyarakat modern. Kehadiran dan keberadaan seorang konsultan pendidikan dibutuhkan masyarakat untuk membantu memberikan pertimbangan-pertimbangan yang obyektif bagi masa depan investasi mereka. Diposisi ini, seorang lulusan Bimbingan Konseling cukup diunggulkan. Karena dalam masa studinya, mahasiswa bimbingan konseling banyak mempelajari mengenai pendidikan dan perkembangan serta diharuskan menguasai kompetensinya. Hal ini jelas berbeda dengan lulusan pendidikan bidang studi tertentu, atau jurusan psikologi yang tidak berkaitan langsung dengan dunia pendidikan.

Di lain pihak, sekolah sebagai institusi pendidikan juga membutuhkan pertimbangan-pertimbangan khusus utamanya dari seorang yang ahli. Untuk menentukan arah dan pencapaian kesuksesan belajar peserta didiknya serta dinamika pendidikan yang semakin kompleks. Akan tetapi, Konsultan pendidikan masih jarang ditemui di tengah-tengah masyarakat.

Kebutuhan masyarakat akan konselor di era pasar global menunjukkan angka yang cukup tinggi. Berbagai macam kasus, mulai dari yang bersifat psikologis hingga kekerasan fisik (seperti KDRT) mewarnai dinamika 
kehidupan masyarakat dewasa ini. Tidak hanya di dunia pendidikan saja, seorang konselor profesional dapat membuka prakteknya. Bidang-bidang lain seperti masalah perkembangan anak dan remaja, keluarga, karier, pernikahan membutuhkan perhatian yang cukup besar.

Jika konselor masih saja membatasi diri dibidang pendidikan. Maka, kemungkinan besar, layanan konseling untuk umum masih akan didominasi oleh psikolog dan psikiater bahkan tenaga-tenaga yang tidak profesional lainnya. Konselor yang mempunyai keahlian dan kompetensi yang lebih ketimbang psikolog atau psikiater mempunyai kesempatan yang masih cukup lebar dalam mengembangkan praktek layanan konseling untuk umum.

Seperti dikatakan C. Gilbert Wrenn dalam karya klasiknya, theWorld of the Contemporary Counselor (1973) yang dikutip dalam Robert L. Gibson dan Marianne H. Mitchell (2011:65) bahwa "kebutuhan utama seorang konselor adalah memahami anak muda zaman sekarang". Pernyataan ini sebenarnya sedang mengacu pada konsep relevansi, yaitu melihat dan memahami lingkungan yang mengelilingi klien disamping selain kondisi klien itu sendiri.

Untuk kedepannya ternyata konselor masih memiliki prospek karir yang bagus dan menjanjikan, tidak hanya didunia pendidikan melainkan juga di luar dunia pendidikan. Prayitno (2009:53) juga telah memaparkan bahwa konselor dapat bekerja dalam berbagai setting kehidupan, diantaranya setting keluarga, setting satuan pendidikan, setting lembaga kerja, setting kelembagaan sosial-kemasyarakatan dan setting praktik privat. Masingmasing setting kehidupan itu memberikan suasana dan ketentuan tersendiri yang perlu mendapatkan perhatian oleh konselor dalam menyelenggarakan pelayanannya.

Tentu saja hal ini merupakan tantangan yang harus dihadapi oleh para pemegang profesi dibidang konseling untuk perkembangan dan kemajuan karirnya di masa mendatang. Tantangan ini akan dapat diterima dan dijalani dengan baik, jika tenaga pelaksana profesi yang akan menerima tantangan tersebut memiliki keahlian profesional dibidang konseling. Karena dengan keahlian profesional tersebutlah mereka dapat menjawab semua tantangan yang dibutuhkan sesuai dengan perkembangan zaman

\section{Perkembangan Profesional Konselor bagi Masyarakat Industri}

Saat memasuki abad baru ini, kita pasti membayangkan masa depan dan perubahan tidak bisa dipisahkan. Perkembangan profesi konseling sendiri bergantung pada generasi pengetahuan baru dan perubahan-perubahan yang distimulasikan pengetahuan baru tersebut. Sejumlah perubahan yang mempengaruhi profesi konselor tengah berlangsung, dan tentunya kita tidak bisa mengandalkan bola kristal untuk memberitahukan arah masa depan profesi konseling selain belajar dari sejarah perkembangan profesi yang ada.

Tantangan memberikan kepada para mahasiswa sesuatu yang maksimal di tengah-tengah pasar global yang sangat kompetitif. Dalam pasar kerja dewasa ini yang sangat kompetitif, perusahaan beroperasi pada tingkat global, keterampilan berbahasa asing dapat membuat perbedaan antara mendapatkan suatu pekerjaan yang baik dan tidak mendapatkan pekerjaan sama sekali. Di lain pihak, penguasaan teknologi juga diperlukan. Calon pekerja profesional harus dapat "melek" teknologi dan dapat menjalankan program-program komputer terutama yang dibutuhkan dalam dunia kerja sesuai dengan bidang kerjanya.

Kemampuan lain yaitu "soft skill" meliputi dapat bekerja secara tim dan organisatoris, mempunyai kemampuan managerial (kepemimpinan) yang baik, interaksi sosial, komunikasi antar pribadi yang efektif, kemampuan berbicara di depan umum, dan lobbying. Mahasiswa atau calon pekerja profesional yang tidak mempunyai "soft skills" tidak akan dapat bertahan lama di dalam dunia kerja. Karena dunia kerja penuh dengan tantangan dan tekanan.

Andrew Singh (dalam Suprayitno, 2006), seorang pakar manajemen dari Singapura, menyatakan bahwa sumber daya manusia dikatakan berkualitas di era modern ini apabila memiliki enam keterampilan, yaitu: speaking skill, thinking skill interpersonal skill, network skill, growth, dan discipline.

Mengadopsi pendapat pakar tersebut, menurut penulis keterampilan-keterampilan tersebut dapat pula diaplikasikan ke dalam profesi konselor sebagai berikut:

a. Speaking Skill (Keterampilan Menyampaikan Gagasan/Berbicara), setiap konselor diharapkan memiliki keterampilan berbicara, bagaimana mengungkapkan gagasan dan pendapat dengan baik, serta memberikan pengarahan dengan baik. Konselor diharapkan dapat berkomunikasi secara efektif. Untuk itu diperlukan penguasaan tidak hanya keterampilan berkomunikasi secara verbal, tetapi juga secara non verbal. 
b. Thinking Skill (Keterampilan Berpikir/Intelektual) kemampuan untuk mendayagunakan otak dengan optimal. Berpikir merupakan sebuah proses memahami realitas dalam rangka mengambil keputusan (decision making), memecahkan masalah (problem solving), untuk itu diperlukan kemampuan berpikir kreatif, sistematis, integratif, logis/rasional, jernih, dan kritis.

c. Interpersonal Skill (Keterampilan Menjaga Hubungan Antarpribadi). Agar komunikasi berjalan efektif dibutuhkan hubungan interpersonal yang baik. Taylor et. al (dalam Rakhmat 2002) menyatakan bahwa banyak penyebab dari rintangan komunikasi berakibat kecil saja bila ada hubungan baik di antara komunikan. Sebaliknya, pesan yang paling jelas, paling tegas, dan paling cermat tidak dapat menghindari kegagalan, jika terjadi hubungan jelek.

d. Network Skill (Keterampilan Mengembangkan, Membangun Jaringan atau Meluaskan Hubungan Kerja). Konselor diharapkan berjiwa kosmopolit, yaitu mampu membangun kontak dengan dunia luar. Dengan membangun jaringan ke luar, maka akan bertambah wawasan, pandangan dan pola pikir. Para konselor akan banyak terbantu dalam menyelesaikan berbagai persoalan tertentu dengan adanya informasi-informasi dari luar.

e. Growth (Keterampilan Diri). Para konselor diharapkan, secara sadar, mau dan mampu untuk secara terus menerus mengembangkan diri ke arah yang lebih baik mampu memperlihatkan kemampuan diri secara optimal, dan mampu mendorong diri sendiri untuk mengembangkan kapasitas prestasi secara optimal. Perlu kesadaran yang timbul dari dalam diri untuk mau menjadi manusia pembelajar.

f. Dicipline (Disiplin). Ketaatan dan kepatuhan serta kerelaan dalam menjalankan tugas sesuai dengan aturan yang berlaku. Setiap konselor secara sadar dan sukarela harus taat pada berbagai ketentuan yang berlaku dan memenuhi standar nilai atau norma yang telah ditetapkan baik yang berlaku di lingkup organisasi, masyarakat, dan agama. Perasaan memiliki dan kecintaan terhadap pekerjaan harus dikembangkan dan menjadi komitmen dalam diri setiap konselor, sehingga akan selalu berusaha untuk memberikan yang terbaik dalam menjalankan profesinya.

Seorang konselor yang profesional tidak hanya harus menguasai kompetensi konseling saja, tetapi juga harus "multi skill", artinya mempunyai banyak kemampuan-kemampuan lain yang menunjang kerja profesional di pasar global. Menurut Robert L. Gibson dan Marianne H. Mitchell (2011:61) menjelaskan beberapa hal yang harus diperhatikan untuk persiapan konselor di masa mendatang :

1. Peningkatan standar bagi penyiapan konselor. di masa datang, konselor harus meningkatkan antisipasi terhadap belajar sepanjang masa, konselor harus terus memperbaiki keterampilan dan pengetahuannya.

2. Meningkatkan perhatian kepada bidang-bidang khusus. Contoh spesifikasi dalam profesi konseling seperti konseling pernikahan, konseling keluarga, konseling karir, konseling krisis, konseling perkembangan dan lain sebagainya.

3. Meningkatkan penggunaan teknologi. Ledakan teknologi yang diproyeksikan terjadi di abad 21 tidak diragukan lagi akan mempengaruhi profesi penolong termasuk konseling.

4. Peningkatan fokus kepada hasil-hasil empiris. Profesi konseling hendaknya banyak memberikan perhatian kepada bukti faktual terdokumentasikan yang dilakukan banyak riset dan studi mengenai aktivitas konselor dan hasil-hasilnya.

5. Pembaharuan teori tradisional profesi. Konselor harus memiliki energi untuk melakukan riset sendiri karena ternyata para teoritis terkemuka saat ini terlibat aktif dalam riset dan pembaharuan teori dibidang konseling.

6. Pembaharuan atensi dan perluasan parameter konseling karir. Keadaan dunia kerja yang banyak berubah, membuat profesi konseling berfikir untuk mempekecil lingkup karir yang lebih khusus. Dapat muncuk konseling profesi, yaitu konseling yang dilatih secara khusus untuk memberikan konseling kepada profesi lain.

7. Meningkatkan perhatian pada komunikasi publik dan aktivitas sosial yang sifatnya politis. Maksudnya untuk mengkomunikasikan kepada publik apa yang sebenarnya dikerjakan para konselor, apa yang sudah dicapai selama ini dan sebagainya.

8. Meningkatkan perhatian pada relevansi program. Landasan untuk mengembankan program yang relevan adalah asesment kebutuhan yang objektif, yang pada gilirannya mengarah kepada pengembangan program konseling yang relevan dan akuntabel. 
Jurnal Konseling dan Pendidikan

9. Meningkatkan kepekaan dan aktivitas multi-budaya. Profesi sebagai konselor yang menjunjung tinggi hubungan positif antar manusia harus mulai bergerak maju dan memimpin masyarakat menuju untuk memunculkan saling pengertian, bahkan kalau bisa mempengaruhi kepemimpinan agar berperan aktif mengatasi segala krisis kemanusiaan.

10. Globalisasi profesionalitas yang semakin meningkat. Peningkatan globalisasi bursa tenaga kerja dan kebijakan ekonomi yang mempengaruhi langsung pekerja dan pemberi kerja sudah menciptakan stres dan ketidakpastian untuk jutaan orang.

11. Peningkatan dramatis konseling online. Perpisahan signifikan dari bentuk konseling tatap muka tradisional adalah revolusi teknologi yang mengusung bentuk konseling online.

\section{KESIMPULAN}

Perubahan sosial yang amat cepat dan makin kompleksnya keadaan masyarakat dewasa ini telah terjadi di seluruh belahan dunia. Perubahan itu melahirkan diferensiasi dan situasi global yang berbeda. Masyarakat industri yang tiap hari disibukkan dengan rutinitas pekerjaan dan kariernya. Bekerja di bawah tekanan dan kecemasan akan kesuksesan dalam kariernya. Bahkan banyak diantara mereka yang melupakan bahwasanya di rumah mereka mempunyai anak-anak dan keluarga yang membutuhkan perhatian lebih dan kasih sayang. Kecenderungan kriminalitas meningkat dan kenakalan remaja serta perbuatan-perbuatan yang melampaui norma-norma sosial semakin subur.

Kehadiran konselor sepertinya menjawab tantangan zaman dan seiring dengan pesatnya kemajuan pasar global. Kantorberita online, careerbuilder.co.uk menulis dan menempatkan konselor dalam 10 besar profesi yang sangat dibutuhkan di dalam masyarakat saat ini. Alasannya dikemukakan bahwa tekanan hidup yang semakin meningkat membuat banyak orang menderita stres dan mengalami kecemasan berlebihan. Karena itu, tenaga konselor merupakan profesi yang dibutuhkan untuk membantu masyarakat dalam menghadapi berbagai permasalahan kehidupan di zaman globalisasi seperti saat sekarang ini.

Seorang calon konselor yang hanya cukup puas dengan kemampuan dan keahlian serta kompetensi yang sudah dikuasai secara benar dibangku perkuliahan saja tanpa membekali dengan kemampuan (skill) lain. Hal ini, jelas akan menjadi pertanyaan besar, "apakah bisa menembus ketatnya persaingan dunia profesi di pasar global?" Sementara dunia globalisasi menuntut pekerja profesional yang handal. Oleh karena itu, untuk dapat bersaing di pasar global konselor memang diharapkan untuk selalu mengembangkan kemampuan profesionalnya dibidang konseling. Arah pengembangan profesional konselor hendaknya disesuaikan dengan kebutuhan pasar global, hingga tenaga konselor dapat membantu masyarakat industri keluar dari berbagai permasalahan yang dihadapinya. Pada akhirnya profesi konselor makin dipercayai di tengah masyarakat dengan keprofesionalan tenaga pelaksananya.

\section{DAFTAR RUJUKAN}

Achmad Juntika Nurihsan. 2007. Bimbingan dan Konseling dalam Berbagai Latar Kehidupan. Bandung: Refika Aditama.

Anas Salahudin. 2010. Bimbingan dan Konseling. Bandung: Pustaka Setia.

Prayitno. 2008. Arah Pemikiran Pengembangan Profesi Konselor. Padang: UNP Press. 2009. Wawasan Profesional Konseling. Padang: UNP Press.

Robert L. Gibson dan Marianne H. Mitchell. 2011. Bimbingan Konseling. Jakarta: Balai Pustaka

Sunaryo Kartadinata. 2005. "Arah dan Tantangan BK Profesional: Proposisi Historik-Futuristik:Tema Perspektif Baru Profesi Konseling di Era Global”. Makalah FIP \& PPS UPI.

UU No. 14 Tahun 2005 tentang Undang-undang Guru dan Dosen. Jakarta: Diknas 